\title{
Copper complexes as a source of redox active MRI contrast agents.
}

Lynsey Dunbar, ${ }^{a}$ Rebecca J. Sowden, ${ }^{b}$ Katherine D. Trotter, ${ }^{a}$ Michelle K.

Taylor, ${ }^{\mathrm{a}, \mathrm{d}}$ David Smith, ${ }^{a}$ Alan R. Kennedy, ${ }^{a}$ John Reglinski* ${ }^{a}$ and Corinne M. Spickett $^{* b, c}$

${ }^{\mathrm{a}}$ Department of Pure \& Applied Chemistry

295 Cathedral St.,

Strathclyde University

Glasgow G1, 1XL

b Strathclyde Institute of Pharmacy and Biomedical Sciences,

27 Taylor Street,

Strathclyde University,

Glasgow G4 0NR.

${ }^{\mathrm{c}}$ Current Address:

School of Life and Health Sciences,

Aston University,

Aston Triangle,

Birmingham, B4 7ET, UK

${ }^{\mathrm{d}}$ Current Address

School of Science and Technology

University of New England

Armidale NSW 2351

Australia

\section{Corresponding author:}

Dr John Reglinski

Fax: 141548 4822;

Tel: 141548 2349;

E-mail: j.reglinski@strath.ac.uk

Key Words: Copper macrocycles, oxidation-reduction, redox sensitive contrast agent, imaging, inflammation. 


\begin{abstract}
The study reports an advance in designing copper-based redox sensing MRI contrast agents. Although the data demonstrate that copper(II) complexes are not able to compete with lanthanoids species in terms of contrast, the redox-dependent switch between diamagnetic copper(I) and paramagnetic copper(II) yields a novel redox-sensitive contrast moiety with potential for reversibility.
\end{abstract}

\title{
Introduction
}

MRI contrast agents capable of detecting redox status in biological tissues would be valuable in the diagnosis of inflammatory diseases that involve an oxidative pathology, such as atherosclerosis or rheumatoid arthritis (Filippin et al. 2008; Profumo et al. 2011). Historically, contrast agents have depended on lanthanide chemistry (De Leon-Rodriguez et al. 2009; Aime et al. 2009) and the development of agents for MRI continues to focus largely on gadolinium owing to its key qualities; i.e. it is a quadrupolar nucleus, it has a large number of unpaired electrons and when coordinatively unsaturated it displays rapid exchange kinetics in aqueous solution (Table 1). However, the synthesis of new, smart imaging agents for measuring biochemical processes (e.g. $\mathrm{pH}$ and $\mathrm{pO}_{2}$ ) requires that the contrast agent has added capability (Angelovski et al. 2008; Iwaki et al. 2012; Viger et al. 2013; Vologdin et al. 2013) A method of introducing added capability is to modify the ligand that chelates the lanthanoid centre (Angelovski et al. 2008; Iwaki et al. 2012; Vologdin et al. 2013). Alternatively, it is possible to encapsulate a gadolinium species into a polymer matrix which degrades in response to the biological environment (Viger et al. 2013).

\section{- Table 1 in here-}


Recent concerns about the nephrotoxicity of gadolinium suggest that there would be advantages in broadening the range of metals used as contrast agents (Badero et al. 2008; Ledneva et al. 2009). The clinical use of transition metals in MRI has been mostly restricted to nanoparticles which, as large multimetallic assemblies, are able to compensate for the weak relaxivity of the parent elements (e.g. iron, copper) (Di Marco et al. 2007; Longmire et al. 2008; Kueny-Stotz et al. 2012; Min et al. 2012). One strategy is to design modified low $\mathrm{T}_{2}$ nano-particles which assemble in the presence of key biomarkers (e.g. streptavidin-biotin) to form assemblies with a high $\mathrm{T}_{2}$ (Min et al. 2012).

Certain transition metals (Table 1) have physical properties compatible with their development as contrast agents (Tobe 1972; Weast 1980; Grant et al. 1997; Lejeune 1999; Yam \& Lo 1999; Dorazio \& Morrow 2012; Drahos et al. 2012; Thunus \& Yu 2012; Loving et al. 2013; Gale et al. 2014; Tsitovich et al. 2014). Since transition metals display different coordination chemistry to gadolinium (lower coordination numbers, simpler topologies) and can combine with a wider range of ligand types (e.g. phosphines, thiolates), it should be easier to target them to physiological parameters such as $\mathrm{pH}$ and redox status.

Due to its large number of unpaired electrons, manganese(II) has attracted the most attention as an alternative to gadolinium (Grant et al. 1997; Thunus \& Lejeune 1999; Yam \& Lo 1999; Yu et al. 2012; Loving et al. 2013; Gale et al. 2014). Indeed, there has been some success with manganese in the design of redox sensing contrast agents (Loving et al. 2013; Gale et al. 2014; Tsitovich et al. 2014). Copper(II) also has some attractive properties (Table 1) (Tobe 1972; Weast 1980). Although it only has one unpaired electron, its ligand exchange rate is higher by two orders of magnitude than manganese and commensurate with that of gadolinium (table 1). Furthermore, its chemistry suggests that it should be easier to create an available coordination site for water without the risk of forming insoluble oxides (c.f. $\mathrm{MnO}_{2}$, $\mathrm{Mn}_{2} \mathrm{O}_{3}$ ). Another advantage of copper over manganese is the availability of a diamagnetic 
form, $d^{10} \mathrm{Cu}(\mathrm{I})$, which can be sustained under biological conditions. The availability of diamagnetic $(\mathrm{Cu}(\mathrm{I}))$ and paramagnetic $(\mathrm{Cu}(\mathrm{II}))$ forms allows the design of agents that have redox switch capability. Lauffer briefly discussed the properties of copper as a platform for the design of imaging agents 25 years ago, deeming it unsuitable for use due to its poor relaxivity (Lauffer 1987). However, the advent of better imaging software, access to higher field strengths, more sophisticated pulse sequences and the emergence of chemical exchange saturation transfer (CEST) as a relaxation mechanism, the need for metals with such high relaxivity may be coming to an end (De Leon-Rodriguez et al. 2009; Aime et al. 2009; Hancu et al 2010; Sherry \& Wu 2013). The design of MRI contrast agents has developed significantly over the past 25 years and it is not uncommon for discrete sensing moieties to be attached directly to a MRI reporting gadolinium species. Thus, should copper remain an unsuitable metal in its own right, there are opportunities to bolster its poor relaxivity by combining a reporting copper complex with a more responsive gadolinium species. Although the relaxivity of copper will never supersede that of manganese or gadolinium, its potential as a switchable redox sensing contrast moiety makes it an interesting target and, considering all the advances in the field of MRI over the past 25 years, a topic worth re-visiting.

\section{Experimental}

Unless otherwise stated, all chemicals were commercially obtained and used without further purification. $\mathrm{Gd}(\mathrm{DTPA})$ and $\mathrm{Cu}\left(\mathrm{BF}_{4}\right)_{2}$ were purchased from the SigmaAldrich company UK. $\mathrm{S}_{\mathrm{pr}} \mathrm{N}_{\mathrm{en}}$ and the unmodified copper macrocycles ([Cu(II)S $\left.\mathrm{en}_{\mathrm{en}}\right]^{2+}$, $\left[\mathrm{Cu}(\mathrm{II}) \mathrm{S}_{\mathrm{en}} \mathrm{N}_{\mathrm{pr}}\right]^{2+}$, $\left[\mathrm{Cu}(\mathrm{II}) \mathrm{S}_{\mathrm{pr}} \mathrm{N}_{\mathrm{en}}\right]^{2+}$ and $\left[\mathrm{Cu}(\mathrm{II}) \mathrm{S}_{\mathrm{pr}} \mathrm{N}_{\mathrm{pr}}\right]^{2+}$ ) were prepared as previously reported (Taylor et al. 2008; Trotter et al. 2009; Trotter et al. 2010; Sowden et al. 2013). Solid reflectance spectra (400 - $900 \mathrm{~nm})$ were recorded on a Photonics CCD array UVVis spectrophotometer. Electrospray mass spectra were recorded using a Thermo 
Finnigan LCQDuo instrument equipped with anion trap as described previously (Taylor et al. 2008; Trotter et al. 2009; Trotter et al. 2010; Sowden et al 2013). The spectrophotometric titrations were carried out on a Unicam UV 300 spectrometer.

X-Ray crystallography: Crystals were coated in mineral oil and mounted on glass fibres. Data were collected at $123 \mathrm{~K}$ on a Nonius Kappa CCD diffractometer using graphite monochromated Mo-K $\alpha$ radiation. The heavy atom positions were determined by Patterson methods and the remaining atoms located in the difference electron density maps. Full matrix least squares refinement was based on $F_{2}$ with all non-hydrogen atoms anisotropic. While the hydrogen atoms were mostly observed in the difference maps, they were placed in calculated positions riding on the parent atoms. The structure solution and refinement used the programs SHELX-97 and the graphical interface WinGX (Sheldrick 1998; Farrugia 1999)

Preparation of $\mathrm{N}$-substituted macrocycles: $\mathrm{S}_{\mathrm{pr}} \mathrm{N}_{\mathrm{en}}(1.04 \mathrm{~g}, 0.003 \mathrm{~mol})$ was dissolved in acetonitrile $(100 \mathrm{~mL})$ to which sodium bicarbonate $(5.07 \mathrm{~g}, 0.06 \mathrm{~mol})$ was added. The mixture was stirred and heated to reflux. Halo-alkane (2-bromo-ethanol, 3-bromopropan-1-ol or bromoacetic acid, 2 mol equiv.) in acetonitrile (50 mL) was added dropwise to the refluxing mixture over a $6 \mathrm{hr}$ period. The mixture was then refluxed overnight. The solution was left to cool, before being filtered. The solvent was removed in vacuo, resulting in a yellow waxy solid. The products were used as received. Yields were typically in the order of $70 \%$.

cis- $\mathrm{S}_{\mathrm{pr}} \mathrm{N}_{\mathrm{en}}\left(-\left(\mathrm{CH}_{2}\right)_{2} \mathrm{OH}\right)_{2}$ : Mass Spec. (ESI) m/z $455.27[\mathrm{M}+\mathrm{Na}]^{+}$. cis- $\mathrm{S}_{\mathrm{pr}} \mathrm{N}_{\mathrm{en}}\left(-\left(\mathrm{CH}_{2}\right)_{3} \mathrm{OH}\right)_{2}$ : Mass Spec. (ESI) m/z $461.14[\mathrm{M}+\mathrm{H}]^{+}$. 
cis- $\mathrm{p}_{\mathrm{pr}} \mathrm{N}_{\mathrm{en}}\left(-\mathrm{CH}_{2} \mathrm{COOH}\right)_{2}$ : Mass Spec. (ESI) $\mathrm{m} / \mathrm{z} 461.13[\mathrm{M}+\mathrm{H}]^{+}$.

Preparation of N-substituted copper(II) macrocycles: The required N-substituted macrocycle $(1.04 \mathrm{~g})$ was dissolved in methanol $(150 \mathrm{~mL})$ and treated with an equimolar amount of $\mathrm{Cu}\left(\mathrm{BF}_{4}\right)_{2} \cdot 6 \mathrm{H}_{2} \mathrm{O}(0.96 \mathrm{~g})$ dissolved in methanol $(10 \mathrm{~mL})$. An immediate colour change from pale yellow to dark green was observed. The resulting solution was refluxed gently overnight. The solution was cooled and filtered and the solvent removed in vacuo to yield a dark green solid. The crude product was redissolved in the minimum amount of methanol, filtered through celite and recrystallised by vapour diffusion using diethyl ether to give a dark green powder.

cis-[Cu(II)S $\left.\mathrm{S}_{\mathrm{pr}} \mathrm{N}_{\mathrm{en}}\left(-\left(\mathrm{CH}_{2}\right)_{2} \mathrm{OH}\right)_{2}\right] 2 \mathrm{BF}_{4}$ : Anal. Calcd. for $\mathrm{C}_{23} \mathrm{H}_{32} \mathrm{~N}_{2} \mathrm{~S}_{2} \mathrm{O}_{2} \mathrm{CuB}_{2} \mathrm{~F}_{8}$ : C, 39.30; H, 4.41; N, 4.36 \% Found: C, 39.98; H, 4.72; N, 4.57 \%. Mass Spec (ESI) m/z $495.08[\mathrm{M}]^{+}, 451.13\left[\mathrm{M}-\mathrm{CH}_{2} \mathrm{CH}_{2} \mathrm{O}\right]^{+} . \lambda_{\max }$ (solid reflectance) $435 \mathrm{~nm}, 640 \mathrm{~nm}$.

cis-[Cu(II) $\left.\mathrm{S}_{\mathrm{pr}} \mathrm{N}_{\mathrm{en}}\left(-\left(\mathrm{CH}_{2}\right)_{3} \mathrm{OH}\right)_{2}\right] 2 \mathrm{BF}_{4}$ : Anal. Calcd. for $\mathrm{C}_{25} \mathrm{H}_{36} \mathrm{~N}_{2} \mathrm{~S}_{2} \mathrm{O}_{2} \mathrm{CuB}_{2} \mathrm{~F}_{8}$ : C, 43.04; H, 5.16; N, 4.02 \% Found: C, 43.83; H, 5.46; N, 3.98 \%. Mass Spec (ESI) m/z $523.20[\mathrm{M}]^{+}, \lambda_{\max }($ solid reflectance) $435 \mathrm{~nm}, 600 \mathrm{~nm}$. XRD data: Monoclinic C2/c, a $=35.7398(14) \AA, \mathrm{b}=9.1810(3) \AA, \mathrm{c}=21.0854(7) \AA, \beta=92.385(3)^{\circ}, \mathrm{V}\left(\AA^{3}\right)$ 6912.7(4), $\mathrm{Z}=8, \mathrm{r}_{\mathrm{obs}}=0.0438, \mathrm{wR}_{2}=0.1104$

cis-[Cu(II)S $\left.\mathrm{S}_{\mathrm{pr}} \mathrm{N}_{\mathrm{en}}\left(-\mathrm{CH}_{2} \mathrm{COOH}\right)_{2}\right] 2 \mathrm{BF}_{4}$ : Anal. Calcd. for $\mathrm{C}_{23} \mathrm{H}_{28} \mathrm{~N}_{2} \mathrm{~S}_{2} \mathrm{O}_{4} \mathrm{CuB}_{2} \mathrm{~F}_{8}$ : C, 41.94; H, 4.44; N, 3.86 \% Found: C, 42.13; H, 4.42; N, 4.02 \%. Mass Spec (ESI) m/z $523.27[\mathrm{M}]^{+} . \lambda_{\max }$ (solid reflectance) $415 \mathrm{~nm}, 600 \mathrm{~nm}$.

cis-[Cu(II)S $\left.\mathrm{S}_{\mathrm{pr}} \mathrm{N}_{\mathrm{en}}\left(-\left(\mathrm{CH}_{2}\right)_{2} \mathrm{SPh}\right)_{2}\right] \quad 2 \mathrm{BF}_{4}$ : Anal. Calcd. for $\mathrm{C}_{35} \mathrm{H}_{40} \mathrm{~N}_{2} \mathrm{~S}_{4} \mathrm{CuB}_{2} \mathrm{~F}_{8}: \mathrm{C}$, 49.22; H, 4.68; N, 3.28 \% Found: C, 49.67; H, 4.79; N, $3.11 \%$. Mass Spec (ESI) m/z $679[\mathrm{M}]^{+}, 543\left[\mathrm{M}-\mathrm{C}_{9} \mathrm{H}_{12} \mathrm{~S}\right]^{+} \lambda_{\max }$ (solid reflectance) $425 \mathrm{~nm}, 610 \mathrm{~nm}$. 
Preparation of $\left[\mathbf{C u}(\mathrm{II}) \mathrm{S}_{\mathrm{pr}} \mathbf{N}_{\mathrm{phen}} \mathbf{R}\right]^{2+} \mathbf{2 B F}_{4}{ }^{-}$: 5-nitro-2-chloro-benzaldehyde (1.86 g, $0.01 \mathrm{~mol}$ ) was dissolved in iso-propylalcohol to which o-phenylenediamine (0.6 g, $0.005 \mathrm{~mol}$ ) was added. The solution was stirred at room temperature for an hour and a yellow precipitate formed. The solution was then filtered and the Schiff base, as a yellow solid, collected and dried.

${ }^{1} \mathrm{H}$ NMR (400 MHz, DMSO; $\left.\delta \mathrm{H}\right) 8.99$ (s, 2H, -CH=N-), 8.92 (d, 2H, arom), 8.29 (dd, 4H, arom), 7.87 (d, 2H, arom), 7.17 (d, 2H, arom), Anal. Calcd. for $\mathrm{C}_{20} \mathrm{H}_{12} \mathrm{Cl}_{2} \mathrm{~N}_{4} \mathrm{O}_{4}$ : C, 54.20; H, 2.73; N, 12.64 \% Found: C, 54.34; H, 2.60; N, 12.83 \% Mass Spec. (ESI) $\mathrm{m} / \mathrm{z} 443[\mathrm{M}+\mathrm{H}]^{+}$

The Schiff base (10 mmol) was dissolved in dichloromethane to which $\mathrm{Cu}\left(\mathrm{BF}_{4}\right)_{2}(0.34 \mathrm{~g}, 10 \mathrm{mmol})$ was added. The compound was heated to reflux and then propanedithiol $(0.09 \mathrm{~g}, 5 \mathrm{mmol})$ added drop-wise. The solution was subsequently refluxed for 48 hours. The solution was then filtered and the solvent removed in vacuo to yield a green-black oil. The crude product was dissolved in distilled water and extracted with dichloromethane and dried over anhydrous sodium sulphate. The solvent was removed to yield the copper Schiff base macrocycle as a green-black oil.

Anal. Calcd. for $\mathrm{C}_{23} \mathrm{H}_{18} \mathrm{~N}_{4} \mathrm{O}_{4} \mathrm{~S}_{2} \mathrm{CuB}_{2} \mathrm{~F}_{8}$ : C, 38.60; H, 2.53; N, $7.83 \%$ Found: C, 40.98; H, 2.60; N, 6.59 \% Mass Spec. (ESI) m/z $541[\mathrm{M}]^{+}$

The Schiff base macrocyclic complex (10 mmol) was dissolved in ethanol (100 ml) and an excess of $\mathrm{NaBH}_{4}(1 \mathrm{~g})$ was added portionwise to the solution and stirred 
overnight. The excess $\mathrm{NaBH}_{4}$ was quenched with ammonium acetate. The solvent was then removed in vacuo to yield a green oil. This was dissolved in distilled water and extracted with dichloromethane and dried over anhydrous sodium sulphate. The solvent was removed in vacuo to yield $\left[\mathrm{Cu}(\mathrm{II}) \mathrm{S}_{\mathrm{pr}} \mathrm{N}_{\mathrm{phen}} \mathrm{R}\right]^{2+} 2 \mathrm{BF}_{4}{ }^{-}$as a green solid.

Anal. Calcd. for $\mathrm{C}_{23} \mathrm{H}_{20} \mathrm{~N}_{4} \mathrm{O}_{4} \mathrm{~S}_{2} \mathrm{CuB}_{2} \mathrm{~F}_{8}$ : C, 38.37; H, 4.42; N, $7.67 \%$ Found: C, 39.03; H, 4.26; N, $7.59 \%$. Mass Spec. (ESI) m/z $543[\mathrm{M}]^{+} . \quad \lambda_{\max }$ (solid reflectance) $425 \mathrm{~nm}, 610 \mathrm{~nm}$.

Relaxation measurements: Relaxation measurements were carried out in triplicate on a Bruker Avance I NMR spectrometer equipped with an $11.7 \mathrm{~T}$ magnet. The measurements were carried out using an inversion recovery pulse sequence under full automation control with a $90^{\circ}$ pulse width of $11.5 \mu \mathrm{s}$. All spectra were referenced internally to the residual proton resonance of the relevant deuterated solvent. The relaxation delay was varied from 1-100 s, depending on the relaxation characteristics of the sample. Data were transferred for remote data processing using Topspin (version 2.1, Bruker Biospin, Karlsruhe) on a desktop PC running under Windows XP. Following Fourier transformation, all data were baseline corrected. The $T_{1} / T_{2}$ subroutine within Topspin was used to evaluate the relevant $\mathrm{T}_{1}$ values from the data.

Samples of the copper macrocycles, GdDTPA and $\mathrm{Cu}\left(\mathrm{BF}_{4}\right)_{2}$ were prepared in $0.1 \mathrm{M} \mathrm{NaCl}, 100 \% \mathrm{D}_{2} \mathrm{O}$ in a $10 \mathrm{~mL}$ volumetric flask at concentrations of $10 \mathrm{mM}, 2.5$ mM, $1 \mathrm{mM}, 0.1 \mathrm{mM}$ and $0.01 \mathrm{mM}$. A control sample of $0.1 \mathrm{mM} \mathrm{NaCl}$ in $100 \% \mathrm{D}_{2} \mathrm{O}$ was also included. 
Electrochemistry: Cyclic voltammetry in aqueous solution was carried out on a $\mathrm{CH}$ Instruments 660A Electrochemical Workstation with iR compensation, using ultra high purity water (Elga: $0.22 \mu \mathrm{m}$ filtered, $17 \mathrm{M} \Omega / \mathrm{cm}$ ) and acetonitrile (redistilled from calcium hydride). The electrodes were glassy carbon, platinum wire and silver wire as the working, counter and reference electrodes, respectively. All solutions were degassed with argon and contained sample concentrations $2 \times 10^{-3} \mathrm{M}$ for acetonitrile, together with the supporting electrolyte; $\mathrm{tBu}_{4} \mathrm{NBF}_{4} \quad\left(\begin{array}{ll}0.1 & \mathrm{M}\end{array}\right)$ respectively. Measurements are referenced against the redox couple $\left(E_{1 / 2}\right)$ of ferrocene / ferrocenium.

Chemical redox cycling: Reduction: A solution of the copper macrocyclic ( $0.3 \mathrm{mM})$ complex and reducing agent (10 mM ascorbic acid) was prepared in Tris-buffer (5 mM $\mathrm{pH}$ 7.4). A $1.0 \mathrm{ml}$ volume of the solution of the complexes was placed in a $1.5 \mathrm{ml}$ quartz cuvette (1 cm pathlength) and the spectrum was recorded (250-800 nm). The solution was titrated with reducing agent in $5 \mu$ l aliquots. The cuvette was allowed to stand for 5 minutes at room temperature to allow the solution to come to equilibrium before the spectrum was recorded. The titrations continued until no further change was observed. Each experiment was carried out in triplicate.

Re-oxidation: A solution of the copper macrocyclic complex $(0.3 \mathrm{mM})$ was prepared in Tris-buffer (5 mM, pH 7.4) and reduced using ascorbic acid from the data above to generate the copper (I) complex in-situ. A $1.0 \mathrm{ml}$ volume of the solution of the required copper complexes was placed in a $1.5 \mathrm{ml}$ quartz cuvette ( $1 \mathrm{~cm}$ pathlength) and the spectrum was recorded (250 - $800 \mathrm{~nm}$ ) against a Tris-buffer reference placed in a matched cuvette. A $100 \mathrm{mM}$ solution of sodium hypochlorite was titrated in $5 \mu \mathrm{l}$ aliquots into the solution. The cuvette was allowed to stand for 5 minutes at room temperature to allow the solution to come to equilibrium before the spectrum was 
recorded. The titrations continued until no further change was observed in the spectra. Each experiment was carried out in triplicate.

\section{Results and Discussion}

As a potential platform for the design of copper-based MRI moieties, we have synthesized and studied three related series of copper complexes (Taylor et al. 2008; Trotter et al. 2009; Trotter et al. 2010; Sowden et al 2013). The first series (Figure. 1) comprise four thioether-secondary amine macrocycles where the alkyl chains linking the donor atoms are modified so as to allow the formation of 14,15 or 16 membered rings. In all of these complexes the macrocycle lies in the meridial plane of the metal. A number of these complexes crystallise with a solvent molecule $\left(\mathrm{MeCN}, \mathrm{H}_{2} \mathrm{O}\right)$ coordinated to the copper atom in an axial position (Taylor et al. 2008; Trotter et al. 2009. This structural feature indicates that a relaxation mechanism similar to that found in Gd(DTPA) should be available with these copper macrocycles. A second series of macrocycles contain tertiary amines have been prepared. Here the pendant arms (X in Figure 1) include a terminal donor atom, which is introduced to increased the denticity of the ligand and the stability of the resulting copper complex. A third system has been synthesised that includes electron withdrawing groups (Figure 1, aryl and $-\mathrm{NO}_{2}$ ) in an attempt to support the copper(I) form better.

\section{-Figure 1 in here-}

The secondary amine copper macrocycles (figure 1 left) were prepared as previously described (Sowden et al 2013) and their relaxation properties assessed in saline solution $\left(0.10 \mathrm{M} \mathrm{NaCl},{ }^{2} \mathrm{H}_{2} \mathrm{O}, 9.4 \mathrm{~T}\right)$. The performance of the species were 
measured against $\mathrm{Gd}(\mathrm{DTPA})$ and $\mathrm{Cu}\left(\mathrm{BF}_{4}\right)_{2}$. $\mathrm{Gd}(\mathrm{DTPA})$ was included as a reference material to demonstrate the relative ability of these copper macrocycles to act as contrast agents. A simple hydrated copper salt $\left(\mathrm{Cu}\left(\mathrm{BF}_{4}\right)_{2}\right)$ was also included in the study to gauge the maximum effect one might expect from copper agents and in turn the influence of the macrocyclic ligand. As expected, the relaxation measurements (Table 2) show that hydrated copper(II) ions have poor relaxivity compared to gadolinium (Lauffer 1987). The hydrated copper(II) cation has a primary coordination sphere of six waters and a weakly bound secondary coordination sphere of up to eight water molecules (Persson 2010). Consequently, it is unsurprising that once the copper is placed within the macrocycles four of the exchange sites are occupied and the relaxivity falls.

\section{- Table 2 in here-}

It has been shown previously that bovine serum albumin (BSA) can efficiently remove the copper from these secondary amine macrocycles (Figure 1, top left) in competitive binding studies (Sowden et al 2013). Thus, although the copper macrocycles have the potential to act as contrast agents, in order to have any real utility the stability of these complexes needs to be increased. Earlier studies have shown that the $\left[\mathrm{Cu}(\mathrm{II}) \mathrm{S}_{\mathrm{pr}} \mathrm{N}_{\mathrm{en}}\right]^{2+}$ motif was marginally more resistant to de-metalation by BSA and this framework was adopted for modification (Sowden et al 2013). Preliminary studies using a tertiary amine complex that incorporates ethanol pendant arms (Figure 1 top right, $\mathrm{X}=$ $\left.\left(\mathrm{CH}_{2}\right)_{2} \mathrm{OH}\right)$ indicated that this modification prevented BSA from removing the metal from the complex (Sowden et al 2013). Mattes et al. have previously synthesised a range of macrocyclic species based on $\left[\mathrm{Cu}(\mathrm{II}) \mathrm{S}_{\mathrm{en}} \mathrm{N}_{\mathrm{en}}\right]^{2+}$ and $\left[\mathrm{Cu}(\mathrm{II})-\mathrm{S}_{\mathrm{en}} \mathrm{N}_{\mathrm{pr}}\right]^{2+}$ ) that have 
ethanol, acetate and pyridyl groups attached to the secondary amines (Funkemeier \& Mattes 1993; Bentfeld et al. 1995; Mattes et al. 2004). In the solid state, these complexes are observed to be cationic, five coordinate species in which the pendant donor oxygen atoms are in the coordination sphere of the copper, lie cis- to one another and are found in their protonated form. The two donor oxygen atoms are included in the coordination geometry at the expense of one of the ring sufur atoms. The $\left[\mathrm{Cu}(\mathrm{II}) \mathrm{S}_{\mathrm{pr}} \mathrm{N}_{\mathrm{en}}\right]^{2+}$ platform has good potential and we have therefore adapted the work of Mattes et al. to introduce ethanol, propanol, acetate and arylthioether pendant arms into this motif (Figure. 1). Although all four complexes were isolated and characterised, only $\left[\mathrm{Cu}(\mathrm{II}) \mathrm{S}_{\mathrm{pr}} \mathrm{N}_{\mathrm{en}}(-\right.$ $\left.\left.\left(\mathrm{CH}_{2}\right)_{3} \mathrm{OH}\right)_{2}\right]^{2+}$ provided X-ray quality crystals. In contrast to the structures reported previously, this complex was found to adopt a five coordinate square based pyramidal structure (Figure 2). Although both alcohol groups are found above the plane of the ligand and are protonated, only one of the hydroxyl groups coordinates. The structures of the corresponding ethanol, acetate thioether adducts remain unclear at this time but we would predict that they are also five coordinate in the solid state (Funkemeier \& Mattes 1993; Bentfeld et al. 1995; Mattes et al. 2004).

\section{-Figure 2 in here-}

The fifth donor atom was introduced into the ligand to increases the stability of the complexes. Typically the stability of a complex is framed using its formation constants, which are then used to hypothesise about the potential biochemistry. We have developed a more direct method of analysis whereby the copper complex is titrated with BSA (Sowden et al 2013). Using this approach, we circumvented the need to calculate each individual formation constant and directly observed if the 
protein can sequester the metal (copper). Using this approach we can show that copper in the five coordinate species are stable to metal sequestration by BSA. ${ }^{\dagger}$ Although the introduction of a fifth donor into the motif has generated a suite of complexes that are suitably bio-tolerant, the increase in stability requires that a fifth water exchange site (c.f. $\left.\mathrm{Cu}\left(\mathrm{BF}_{4}\right)_{2}\right)$ is occupied and consequently the relaxivity of the complexes falls (Table 2).

The ability of the compounds to act as redox sensing contrast agents requires that they have redox reversibility between the copper(II) and copper(I) forms. The issue of redox reversibility has been interrogated in two ways: electrochemically and chemically. Electrochemical analysis of the compounds (Table 1) shows that the addition of the pendant arms has raised the $\mathrm{E}^{0}$ of the complexes significantly. Surprisingly, the addition of electron withdrawing groups (i.e. $\left[\mathrm{Cu}(\mathrm{II}) \mathrm{S}_{\mathrm{pr}} \mathrm{N}_{\mathrm{phen}} \mathrm{R}\right]^{2+}$ ) and soft donor moieties ([Cu(II) $\left.\left.\mathrm{S}_{\mathrm{pr}} \mathrm{N}_{\mathrm{en}}\left(\left(-\mathrm{CH}_{2}\right)_{2} \mathrm{SPh}\right)_{2}\right]^{2+}\right)$ into the motif has little impact on redox potential of the copper centre and the values obtained for these species (1.2-1.5 V) consistently come to the higher end of the desired range (table 2). The voltammograms of compounds indicate that the addition of pendant arm donor moieties renders the complexes irreversible except in one case i.e. ([Cu(II) $\mathrm{S}_{\mathrm{pr}} \mathrm{N}_{\mathrm{en}}((-$ $\left.\left.\left.\mathrm{CH}_{2}\right)_{2} \mathrm{SPh}\right)_{2}\right]^{2+}$ ). This compound shows good reversibility at a range of scan rates (Figure 3.). This indicates that an increase in the sulphur density around the copper centre is having a beneficial effect and that the additional soft donors is able to support the formation of the copper(I) species during redox cycling better.

\footnotetext{
- Figure 3 in here-
}

-figure 4 in here- 
In our previous studies we investigated the redox chemistry of our compounds by subjecting them to chemical redox cycling using ascorbic acid reduction followed by hypochlorite oxidation (Taylor et al. 2008; Trotter et al. 2009; Trotter et al. 2010; Sowden et al 2013). Repeating this approach here, we found behaviour which paralleled the electrochemical study above. While all the compounds could be stoichiometrically reduced, only $\left[\mathrm{Cu}(\mathrm{II}) \mathrm{S}_{\mathrm{pr}} \mathrm{N}_{\mathrm{en}}\left(\left(\mathrm{CH}_{2}\right)_{2} \mathrm{SPh}\right)_{2}\right]^{2+}$ could be efficiently reoxidised ( 85\%) back to the divalent state (Fig 4.). The ability to re-oxidise $\left[\mathrm{Cu}(\mathrm{II}) \mathrm{S}_{\mathrm{pr}} \mathrm{N}_{\mathrm{en}}\left(\left(\mathrm{CH}_{2}\right)_{2} \mathrm{SPh}\right)_{2}\right]^{2+}$ is a significant improvement over the previous compounds studied (table 1) (Taylor et al. 2008; Trotter et al. 2009; Trotter et al. 2010; Sowden et al 2013). However, whereas reduction remains stoichiometric, re-oxidation still required an excess of oxidant to effect the redox switch.

\section{Conclusions}

Here we present the first major effort to explore copper's ability to be used as a redox-sensitive MRI moiety. As predicted by Lauffer (1987), the relaxivity of these copper based species is poor compared with gadolinium and considerable further development is needed before copper will be able to perform independently as a redox sensitive contrast agent. The study does indicate that it should be possible to generate a compound which is stable in both the +1 and +2 oxidation states under biological conditions with an appropriate oxidation potential. However, it is clear that for these compounds to have any use in MRI they will have to be coupled with a higher relaxivity metal such as gadolinium. Finally, it would be better if the sensing agent was administered in its low valent form and the challenge now is to produce copper(I) complexes of this type that respond to oxidants rather than copper(II) complexes which respond to reductants. 


\section{Acknowledgements}

L.D., K.D.T., M.K.T. and D.S. would like to thank Strathclyde University and WestChem for financial assistance. J.R., C.M.S. and R.J.S. gratefully acknowledge the support of the BBSRC (BBS/B/01553).

\section{Electronic Supplementary Information (ESI) available:}

Details of the X-ray crystal structure determination of $\left[\mathrm{Cu}(\mathrm{II}) \mathrm{S}_{\mathrm{pr}} \mathrm{N}_{\mathrm{en}}(-\right.$ $\left.\left.\left(\mathrm{CH}_{2}\right)_{3} \mathrm{OH}\right)_{2}\right] 2 \mathrm{BF}_{4}$ may be obtained from the CCDC; e-mail deposit@ccdc.cam.ac.uk or www:http://ccdc. cam.ac.uk) on request quoting the depository numbers ccdc 953160. ${ }^{\dagger}$ The supporting information contains details on the competitive binding studies of the macrocycles with BSA.

\section{Notes and references}

It should be noted that Kupka et al. (1992) made a brief comment on the potential use of copper(II) D-penicillamine as a contrast agent in plants. To our knowledge this work did not develop further.

\section{References}

Aime S, Castelli DD, Crich SG, Gianolio GE, Terreno E Pushing the Sensitivity Envelope of Lanthanide-Based Magnetic Resonance Imaging (MRI) Contrast Agents for Molecular Imaging Applications (2009) Acc Chem Res 42: 822-831. 
Angelovski G, Fouskova P, Mamedov I, Canals S, Toth E, Logothetis NK Smart magnetic resonance imaging agents that sense extracellular calcium fluctuations (2008) ChemBioChem, 9: $1729-1734$.

Badero OJ, Schlanger L, Rizk D, Gadolinium nephrotoxicity: case report of a rare entity and review of the literature (2008) Clin Nephr 70: 518-522.

Bentfeld R, Ehlers N, Mattes R, Synthesis and characterization of copper(II) complexes of a 14-membered cis- $\mathrm{N}_{2} \mathrm{~S}_{2}$ dibenzo macrocycle and of its bis-acetato and bis(methylpyridyl) derivatives (1995) Chem Ber 128: 1199-1205

De Leon-Rodriguez LM, Lubag AJM, Malloy CR, Martinez GV, Gillies RJ, Sherry AD Responsive MRI Agents for Sensing Metabolism in Vivo (2009) Acc Chem Res 42: 948-957.

Di Marco M, Sadun C, Port M, Guilbert I, Couvreur P, Dubernet C Physicochemical characterization of ultrasmall superparamagnetic iron oxide particles (USPIO) for biomedical application as MRI contrast agents (2007) Int J Nanomed 2; 609-622.

Dorazio S, Morrow JR, The Development of Iron(II) Complexes as ParaCEST MRI Contrast Agents (2012) Eur J Inorg Chem 2006-2014. Drahos B, Lukes I, Toth E, Manganese(II) Complexes as Potential Contrast Agents for MRI (2012) Eur J Inorg Chem 1975-1986.

Farrugia LJ, WinGX suite for small-molecule single-crystal crystallography (1999) J. Appl. Crystallogr. 1999, 32, 837-838. 
Filippin LI, Vercelino V, Marroni NP, Xavier RM, Redox signalling and the inflammatory response in rheumatoid arthritis (2008) Clin Exper Immunol 152: 415-422.

Funkemeier D, Mattes R, Synthesis and structural studies of copper(II), nickel(II) and cobalt(II) complexes of a 14-membered trans- $\mathrm{N}_{2} \mathrm{~S}_{2}$ dibenzo macrocycle with 2 pendant pyridylmethyl groups (1993) J Chem Soc Dalton Trans 1313-1319.

Gale EM, Mukherjee S, Liu C, Loving GS, Caravan P, Structure-Redox-Relaxivity Relationships for Redox Responsive Manganese-Based Magnetic Resonance Imaging Probes (2014) Inorg Chem 53: 10748-10761.

Grant D, Refsum H, Rummeny E, Marchal G, Liver imaging: Clinical applications and future perspectives (1997) Acta Radiol 38: 623-630.

Hancu I, Dixon WT, Woods M, Vinogradov E, Sherry AD, Lenkinski RE, CEST and PARACEST MR contrast agents (2010) Acta Radiol 51: 910-923.

Iwaki S, Hanaoka K, Piao W, Komatsu T, Ueno T, Terai T, Nagano T, Development of hypoxia-sensitive Gd3+-based MRI contrast agents (2012) Bioorg Med Chem Lett 22: 27982892

Kueny-Stotz M, Garofalo A, Felder-Flesch D Manganese-Enhanced MRI Contrast Agents: From Small Chelates to Nanosized Hybrids (2012) Eur J Inorg Chem 1987-2005. 
Kupka T, Dziegielewski JO, Pasterna G, Malecki JG, Copper-D-penicillamine complex as potential contrast agent for MRI (1992) Mag Reson Imag 10: 855-858

Lauffer RB, Paramagnetic metal complexes as water proton relaxation agents for NMR imaging: theory and design (1987) Chem Rev 87: 901-927

Ledneva E, Karie S, Launay-Vacher V, Janus N, Deray G Renal Safety of Gadolinium-based Contrast Media in Patients with Chronic Renal Insufficiency (2009) Radiology 250; 618-628.

Longmire M, Choyke PL, Kobayashi H, Clearance properties of nano-sized particles and molecules as imaging agents: considerations and caveats (2008) Nanomed 3; 703-717;

Loving GS, Mukherjee S, Caravan P, Redox-Activated Manganese-Based MR Contrast Agent (2013) J Amer Chem Soc 135: 4620-4623.

Mattes R, Muhlenbrock C, Leeners K, Pyttel C, Metal complexes with $\mathrm{N}_{2} \mathrm{O}_{2} \mathrm{~S}_{2}$ donor set. Synthesis and characterization of the cobalt(II), nickel(II), and copper(II) complexes of a 15and a 16-membered bis(2-hydroxyethyl) pendant macrocyclic ligand. (2004) Z Anorg Allg Chem 630: 722-729.

Min C, Shao H, Liong M, Yoon T-J, Weissleder R, Lee H Mechanism of Magnetic Relaxation Switching Sensing (2012) ACS Nano 6; 6821-6828.

Persson I, Hydrated metal ions in aqueous solution: How regular are their structures? (2010) Pure Appl Chem 82: 1901-1917. 
Profumo E, Buttari B, Rigano R Oxidative stress in cardiovascular inflammation: its involvement in autoimmune responses (2011) Int J Inflamm Article ID 295705.

Sheldrick GM, SHELXL-97. Programs for crystal structure analysis (release 97-2), Institut für Anorganische Chemie der Universität Göttingen, Tammanstrasse 4, D-3400 Gottingen, Germany (1998).

Sherry AD, Wu YK, The importance of water exchange rates in the design of responsive agents for MRI (2013) Curr Opin Chem Biol. 17: 167-174.

Sowden RJ, Trotter KD, Dunbar L, Craig G, Erdemli O, Spickett CM, Reglinski J, Reactions of Copper Macrocycles with Antioxidants and HOCl: Potential for Biological Redox Sensing (2013) Biometals 26: 85-95.

Taylor MK, Trotter KD, Reglinski J, Berlouis LEA, Kennedy AR, Spickett CM, Sowden RJ, Copper $\mathrm{N}_{2} \mathrm{~S}_{2}$ Schiff base macrocycles: The effect of structure on redox potential (2008) Inorg Chim Acta 361: 2851-2862.

Thunus L, Lejeune R, Overview of transition metal and lanthanide complexes as diagnostic tools (1999) Coord Chem Revs 184: 125- 155.

Tobe ML in Inorganic Reaction Mechanisms. (1972) Thomas Nelson \& Sons Ltd London. 
Trotter KD, Reglinski J, Robertson K, Forgie JC, Parkinson JA, Kennedy AR, Armstrong DR, Sowden RJ, Spickett CM, Structural Studies of trans- $\mathrm{N}_{2} \mathrm{~S}_{2}$ Copper Macrocycles (2009) Inorg Chim Acta 362: 4065-4072.

Trotter KD, Taylor MK, Forgie JC, Reglinski J, Berlouis LEA, Kennedy AR, Spickett CM, Sowden RJ, The structural and electrochemical consequences of hydrogenating Copper $\mathrm{N}_{2} \mathrm{~S}_{2}$ Schiff base macrocycles (2010) Inorg Chim Acta 363: 1529-1538.

Tsitovich PB, Burns PJ, Mckay AM, Morrow JR, Redox-activated MRI contrast agents based on lanthanide and transition metal ions (2014) J Inorg Biochem 133: 143-154.

Viger ML, Sankaranarayanan J, de Gracia Lux C, Chan M, Almutairi A Collective Activation of MRI Agents via Encapsulation and Disease-Triggered Release (2013) J Amer Chem Soc 135: 7847-7850.

Vologdin N, Rolla GA, Botta M, Tei L, Orthogonal synthesis of a heterodimeric ligand for the development of the Gd-III-Ga-III ditopic complex as a potential pH-sensitive MRI/PET probe (2013) Org Biomol Chem 11: 1683-1690;

Weast RC in Handbook of Chemistry \& Physics, 60th Edition, CRC Press 1980 Yam VWW, Lo KKW, Recent advances in utilization of transition metal complexes and lanthanides as diagnostic tools (1999) Coord Chem Revs 184: 157-240. 
Yu M, Beyers RJ, Gorden JD, Cross NJ, Goldsmith CR, A Magnetic Resonance Imaging Contrast Agent Capable of Detecting Hydrogen Peroxide (2012) Inorg Chem 51: 9153-9155.

\section{Table Captions}

Table 1. The properties of gadolinium and certain first row transition metal species key to their ability to perform as contrast agents (Tobe 1972, Handbook of Chemistry 1980). Unlike the lanthanoids, the exchange kinetics and number of unpaired electrons vary more widely and are governed by the prevailing oxidation state and ligand field considerations. Oh denotes an octahedral geometry

Table 2. Relaxivity and electrochemical data: The relaxivity of GdDTPA, $\mathrm{Cu}\left(\mathrm{BF}_{4}\right)_{2}$, $\left[\mathrm{Cu}(\mathrm{II}) \mathrm{S}_{\mathrm{en}} \mathrm{N}_{\mathrm{en}}\right]^{2+} ;\left[\mathrm{Cu}(\mathrm{II}) \mathrm{S}_{\mathrm{pr}} \mathrm{N}_{\mathrm{en}}\right]^{2+} ;\left[\mathrm{Cu}(\mathrm{II}) \mathrm{S}_{\mathrm{en}} \mathrm{N}_{\mathrm{pr}}\right]^{2+} ;\left[\mathrm{Cu}(\mathrm{II}) \mathrm{S}_{\mathrm{pr}} \mathrm{N}_{\mathrm{pr}}\right]^{2+} ;\left[\mathrm{Cu}(\mathrm{II}) \mathrm{S}_{\mathrm{pr}} \mathrm{N}_{\mathrm{en}}(\mathrm{X})_{2}\right]^{2+}$, where $\mathrm{X}=-\left(\mathrm{CH}_{2}\right)_{2} \mathrm{OH},-\left(\mathrm{CH}_{2}\right)_{3} \mathrm{OH},-\mathrm{CH}_{2} \mathrm{COOH},-\left(\mathrm{CH}_{2}\right)_{2} \mathrm{SPh}$ and $\left[\mathrm{Cu}(\mathrm{II}) \mathrm{S}_{\mathrm{pr}} \mathrm{N}_{\text {phen }} \mathrm{R}\right]^{2+}(\mathrm{n}=$ 3) in $0.1 \mathrm{M} \mathrm{NaCl}$ in ${ }^{2} \mathrm{H}_{2} \mathrm{O}$ at 9.4T. . Electrochemical data for the copper macrocycles in acetonitrile $\left(0.1 \mathrm{M}^{\mathrm{t}} \mathrm{Bu}_{4} \mathrm{NBF}_{4}\right.$ : The values for the complexes are expressed relative to the normal hydrogen electrode (HNE) (Taylor et al. 2008)

\section{Figure Captions}

Figure 1 The copper macrocyclic frameworks studied (Taylor et al. 2008; Trotter et al. 2009; Trotter et al. 2010; Sowden et al. 2013). (a) Secondary amine complexes, where the polymethylene chains between the nitrogen and sulfur donor atoms are ethylene (en) or propylene (pr) giving rise to four compounds: $\left[\mathrm{Cu}(\mathrm{II}) \mathrm{S}_{\mathrm{en}} \mathrm{N}_{\mathrm{en}}\right]^{2+},\left[\mathrm{Cu}(\mathrm{II}) \mathrm{S}_{\mathrm{en}} \mathrm{N}_{\mathrm{pr}}\right]^{2+}$, $\left[\mathrm{Cu}(\mathrm{II}) \mathrm{S}_{\mathrm{pr}} \mathrm{N}_{\mathrm{en}}\right]^{2+}$ and $\left[\mathrm{Cu}(\mathrm{II}) \mathrm{S}_{\mathrm{pr}} \mathrm{N}_{\mathrm{pr}}\right]^{2+}$. (b) Tertiary amine complexes $\left[\mathrm{Cu}(\mathrm{II}) \mathrm{S}_{\mathrm{pr}} \mathrm{N}_{\mathrm{en}}(\mathrm{X})_{2}\right]^{2+}$, where $\mathrm{X}=-\left(\mathrm{CH}_{2}\right)_{2} \mathrm{OH},-\left(\mathrm{CH}_{2}\right)_{3} \mathrm{OH},-\mathrm{CH}_{2} \mathrm{COOH}$ or $-\left(\mathrm{CH}_{2}\right)_{2} \mathrm{SPh}$. (c) $\left[\mathrm{Cu}(\mathrm{II}) \mathrm{S}_{\mathrm{pr}} \mathrm{N}_{\mathrm{phen}} \mathrm{R}\right]^{2+}$ where additional electron withdrawing groups (aryl, $-\mathrm{NO}_{2}$ ) are included in the motif. 
Figure 2. The X-ray crystal structure of $\left[\mathrm{Cu}(\mathrm{II}) \mathrm{S}_{\mathrm{pr}} \mathrm{N}_{\mathrm{en}}\left(-\left(\mathrm{CH}_{2}\right)_{3} \mathrm{OH}\right)_{2}\right]^{2+}$. The counter ions $\left(\mathrm{BF}_{4}^{-}\right)$are omitted for clarity. The copper sits in a distorted square based pyramidal geometry. The hydrogens on the oxygens were found during refinement. The thermal ellipsoids are shown at 50\% probability. Selected metrical parameters (d/Å, $\left.{ }^{\circ}\right) \mathrm{Cu}-\mathrm{S}$ 2.3450(7), 2.3487(7); Cu-N 2.045(2), 2.052(2); Cu-O 2.1725(18); <S-Cu-N ( $\left.{ }^{\circ}\right), 163.00(6)$, 93.48(6), 176.82(6), 93.49(6).

Figure 3. The cyclic voltammogramm of $\left[\mathrm{Cu}(\mathrm{II}) \mathrm{S}_{\mathrm{pr}} \mathrm{N}_{\mathrm{en}}\left(\left(\mathrm{CH}_{2}\right)_{2} \mathrm{SPh}\right)_{2}\right] 2 \mathrm{BF}_{4}(2 \mathrm{mM})$ in acetonitrile $/{ }^{t} \mathrm{BuNBF}_{4}(0.1 \mathrm{M})$ at scan rates of $10,40,80,120,160$ and $200 \mathrm{mVs}^{-1}$. The $\mathrm{E}^{0}$ values (table 2) were referenced to the normal hydrogen electrode using a ferrocene standard.

Figure 4. The chemical reduction of $\left[\mathrm{Cu}(\mathrm{II}) \mathrm{S}_{\mathrm{pr}} \mathrm{N}_{\mathrm{en}}\left(\left(\mathrm{CH}_{2}\right)_{2} \mathrm{SPh}\right)_{2}\right]^{2+}$ by ascorbic acid (left) followed by the chemical re-oxidation using hypochlorite (right). The figure is a composite of the data from two separate titrations. 
Table 1

\begin{tabular}{|c|c|c|c|c|}
\hline \multirow[b]{2}{*}{ Gd } & \multirow{2}{*}{$\begin{array}{l}\text { No. unpaired electrons and } \\
\text { relevant oxidation state } \\
7\end{array}$} & \multicolumn{2}{|c|}{$\begin{array}{l}\text { Nuclear spin } \\
\text { (abundance \%) }\end{array}$} & \multirow{2}{*}{$\begin{array}{l}\text { Exchange rate } \\
\qquad \begin{array}{c}\left(\mathrm{s}^{-1}\right) \\
10^{9}\end{array}\end{array}$} \\
\hline & & $3 / 2^{155} \mathrm{Gd}$ & (14.7) & \\
\hline & & $3 / 2{ }^{157} \mathrm{Gd}$ & $(15.7)$ & \\
\hline $\mathrm{V}$ & 2 (III) & $7 / 2{ }^{51} \mathrm{~V}$ & (99.8) & $10^{3}$ \\
\hline \multirow[t]{2}{*}{$\mathrm{Cr}$} & 4 (II) & $3 / 2{ }^{53} \mathrm{Cr}$ & $(9.6)$ & $10^{9}$ \\
\hline & 3 (III) & & & $5 \times 10^{-5}$ \\
\hline Mn & 7 (II) & $5 / 2{ }^{55} \mathrm{Mn}$ & $(100)$ & $5 \times 10^{7}$ \\
\hline Co & 3 (II) high spin $\mathrm{O}_{\mathrm{h}}$ & $7 / 2{ }^{59} \mathrm{Co}$ & $(100)$ & $5 \times 10^{6}$ \\
\hline & 0 (III) low spin $\mathrm{O}_{\mathrm{h}}$ & & & $5 \times 10^{-5}$ \\
\hline \multirow[t]{2}{*}{$\mathrm{Cu}$} & 1 (II) & $3 / 2{ }^{63} \mathrm{Cu}$ & $(69.1)$ & $10^{9}$ \\
\hline & 0 (I) & $3 / 2{ }^{65} \mathrm{Cu}$ & (30.9) & \\
\hline
\end{tabular}

Table 1. The properties of gadolinium and certain first row transition metal species key to their ability to perform as contrast agents (Tobe 1972, Handbook of Chemistry 1980). Unlike the lanthanoids, the exchange kinetics and number of unpaired electrons vary more widely and are governed by the prevailing oxidation state and ligand field considerations. Oh denotes an octahedral geometry 
Table 2

\begin{tabular}{|c|c|c|c|}
\hline & Compound & Relaxivity s ${ }^{-1} \mathrm{mM}^{-1}$ & $E^{0} V$ \\
\hline Reference & Gd(DTPA) & 4.73 & \\
\hline compounds & $\mathrm{Cu}^{\mathrm{II}}\left(\mathrm{BF}_{4}\right)_{2}$ & 0.67 & \\
\hline \multirow{3}{*}{$\begin{array}{c}\text { Simple macrocycles } \\
\text { (Fig 1a) }\end{array}$} & {$\left[\mathrm{Cu}(\mathrm{II}) \mathrm{S}_{\mathrm{en}} \mathrm{N}_{\mathrm{pr}}\right]^{2+}$,} & $0.27 \pm 0.03$ & $0.65^{* \mathrm{c}}$ \\
\hline & {$\left[\mathrm{Cu}(\mathrm{II}) \mathrm{S}_{\mathrm{pr}} \mathrm{N}_{\mathrm{en}}\right]^{2+}$} & $0.27 \pm 0.01$ & 0.85 (57\%) \\
\hline & {$\left[\mathrm{Cu}(\mathrm{II}) \mathrm{S}_{\mathrm{pr}} \mathrm{N}_{\mathrm{pr}}\right]^{2+}$} & $0.26 \pm 0.03$ & $0.85^{* \mathrm{c}}$ \\
\hline \multirow{4}{*}{$\begin{array}{c}\text { Pendant arm } \\
\text { macrocycles } \\
{\left[\mathrm{Cu}(\mathrm{II}) \mathrm{S}_{\mathrm{pr}} \mathrm{N}_{\mathrm{en}}(\mathrm{X})_{2}\right]^{2+}} \\
(\text { Fig } 1 \mathrm{~b})\end{array}$} & $\overline{\mathrm{X}}=-\left(\mathrm{CH}_{2}\right)_{2} \mathrm{OH}$ & $0.42 \pm 0.02$ & $1.04(22 \%)$ \\
\hline & $\mathrm{X}=-\left(\mathrm{CH}_{2}\right)_{3} \mathrm{OH}$ & $0.16 \pm 0.02$ & $1.23(21 \%$ \\
\hline & $\mathrm{X}=-\mathrm{CH}_{2} \mathrm{COOH}$ & $0.11+0.01$ & 1.44 (24\%) \\
\hline & $\mathrm{X}=-\left(\mathrm{CH}_{2}\right)_{2} \mathrm{SPh}$ & $0.12 \pm 0.02$ & $1.28(79 \%)$ \\
\hline $\begin{array}{l}\text { Macrocycle-EWG } \\
\text { (Fig 1c) }\end{array}$ & 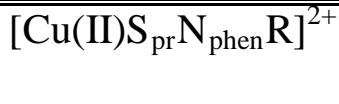 & $0.11 \pm 0.02$ & $1.42(9 \%)$ \\
\hline
\end{tabular}

Relaxivity and electrochemical data: The relaxivity of GdDTPA, $\mathrm{Cu}\left(\mathrm{BF}_{4}\right)_{2}$,

$\left[\mathrm{Cu}(\mathrm{II}) \mathrm{S}_{\mathrm{en}} \mathrm{N}_{\mathrm{en}}\right]^{2+} ;\left[\mathrm{Cu}(\mathrm{II}) \mathrm{S}_{\mathrm{pr}} \mathrm{N}_{\mathrm{en}}\right]^{2+} ;\left[\mathrm{Cu}(\mathrm{II}) \mathrm{S}_{\mathrm{en}} \mathrm{N}_{\mathrm{pr}}\right]^{2+} ;\left[\mathrm{Cu}(\mathrm{II}) \mathrm{S}_{\mathrm{pr}} \mathrm{N}_{\mathrm{pr}}\right]^{2+}$;

$\left[\mathrm{Cu}(\mathrm{II}) \mathrm{S}_{\mathrm{pr}} \mathrm{N}_{\mathrm{en}}(\mathrm{X})_{2}\right]^{2+}$, where $\mathrm{X}=-\left(\mathrm{CH}_{2}\right)_{2} \mathrm{OH},-\left(\mathrm{CH}_{2}\right)_{3} \mathrm{OH},-\mathrm{CH}_{2} \mathrm{COOH},-\left(\mathrm{CH}_{2}\right)_{2} \mathrm{SPh}$ and $\left[\mathrm{Cu}(\mathrm{II}) \mathrm{S}_{\mathrm{pr}} \mathrm{N}_{\text {phen }} \mathrm{R}\right]^{2+}(\mathrm{n}=3)$ in $0.1 \mathrm{M} \mathrm{NaCl}$ in ${ }^{2} \mathrm{H}_{2} \mathrm{O}$ at 9.4T. . Electrochemical data for the copper macrocycles in acetonitrile $\left(0.1 \mathrm{M}^{t} \mathrm{Bu}_{4} \mathrm{NBF}_{4}\right.$ : The values for the complexes are expressed relative to the normal hydrogen electrode (HNE). * (Taylor 2008) 


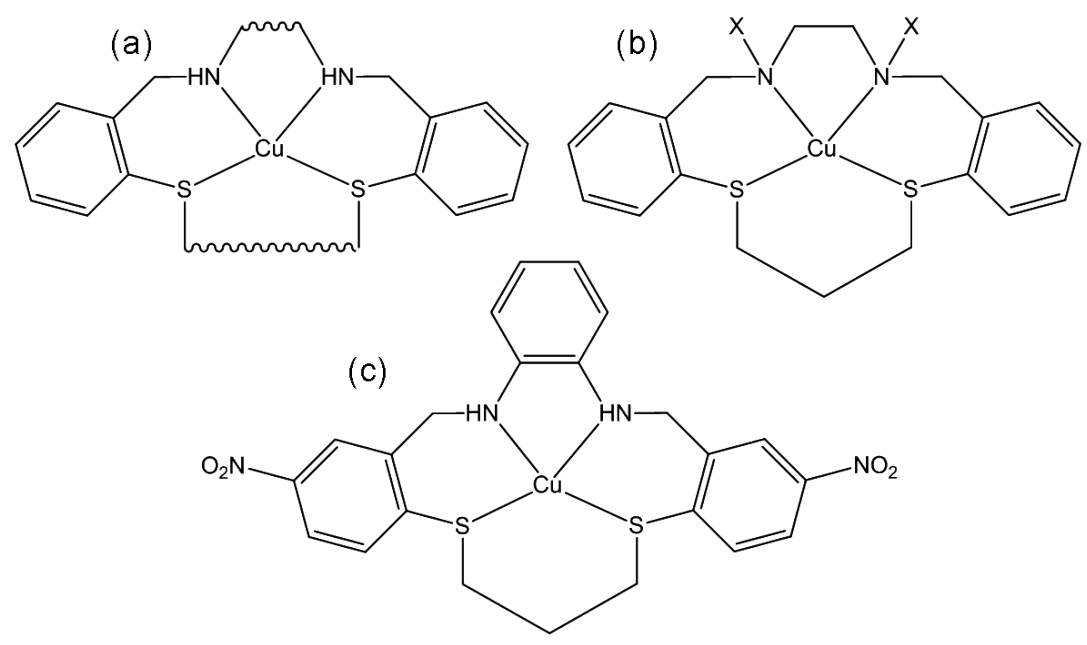

Figure 1. The copper macrocyclic frameworks studied (Taylor et al. 2008; Trotter et al. 2009; Trotter et al. 2010; Sowden et al. 2013). (a) Secondary amine complexes, where the polymethylene chains between the nitrogen and sulfur donor atoms are ethylene (en) or propylene (pr) giving rise to four compounds: $\left[\mathrm{Cu}(\mathrm{II}) \mathrm{S}_{\mathrm{en}} \mathrm{N}_{\mathrm{en}}\right]^{2+}$, $\left[\mathrm{Cu}(\mathrm{II}) \mathrm{S}_{\mathrm{en}} \mathrm{N}_{\mathrm{pr}}\right]^{2+}$, $\left[\mathrm{Cu}(\mathrm{II}) \mathrm{S}_{\mathrm{pr}} \mathrm{N}_{\mathrm{en}}\right]^{2+}$ and $\left[\mathrm{Cu}(\mathrm{II}) \mathrm{S}_{\mathrm{pr}} \mathrm{N}_{\mathrm{pr}}\right]^{2+}$. (b) Tertiary amine complexes $\left[\mathrm{Cu}(\mathrm{II}) \mathrm{S}_{\mathrm{pr}} \mathrm{N}_{\mathrm{en}}(\mathrm{X})_{2}\right]^{2+}$, where $\mathrm{X}=-$ $\left(\mathrm{CH}_{2}\right)_{2} \mathrm{OH},-\left(\mathrm{CH}_{2}\right)_{3} \mathrm{OH},-\mathrm{CH}_{2} \mathrm{COOH}$ or $-\left(\mathrm{CH}_{2}\right)_{2} \mathrm{SPh}$. (c) $\left[\mathrm{Cu}(\mathrm{II}) \mathrm{S}_{\mathrm{pr}} \mathrm{N}_{\text {phen }} \mathrm{R}\right]^{2+}$ where additional electron withdrawing groups (aryl, $-\mathrm{NO}_{2}$ ) are included in the motif.

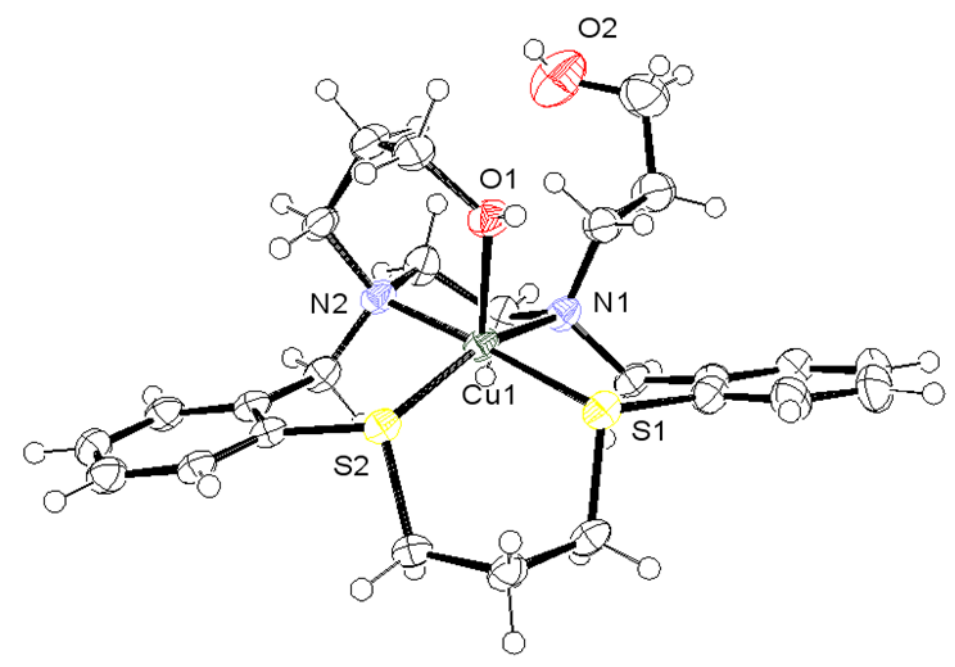

Figure 2. The X-ray crystal structure of $\left[\mathrm{Cu}(\mathrm{II}) \mathrm{S}_{\mathrm{pr}} \mathrm{N}_{\mathrm{en}}\left(-\left(\mathrm{CH}_{2}\right)_{3} \mathrm{OH}\right)_{2}\right]^{2+}$. The counter ions $\left(\mathrm{BF}_{4}^{-}\right)$are omitted for clarity. The copper sits in a distorted square based pyramidal geometry. The hydrogens on the oxygens were found during refinement. The thermal ellipsoids are shown at 50\% probability. Selected metrical parameters (d/Å, $\left.{ }^{\circ}\right)$ Cu-S 2.3450(7), 2.3487(7); Cu-N 2.045(2), 2.052(2); Cu-O 2.1725(18); <S-Cu-N (०), 163.00(6), 93.48(6), 176.82(6), 93.49(6). 


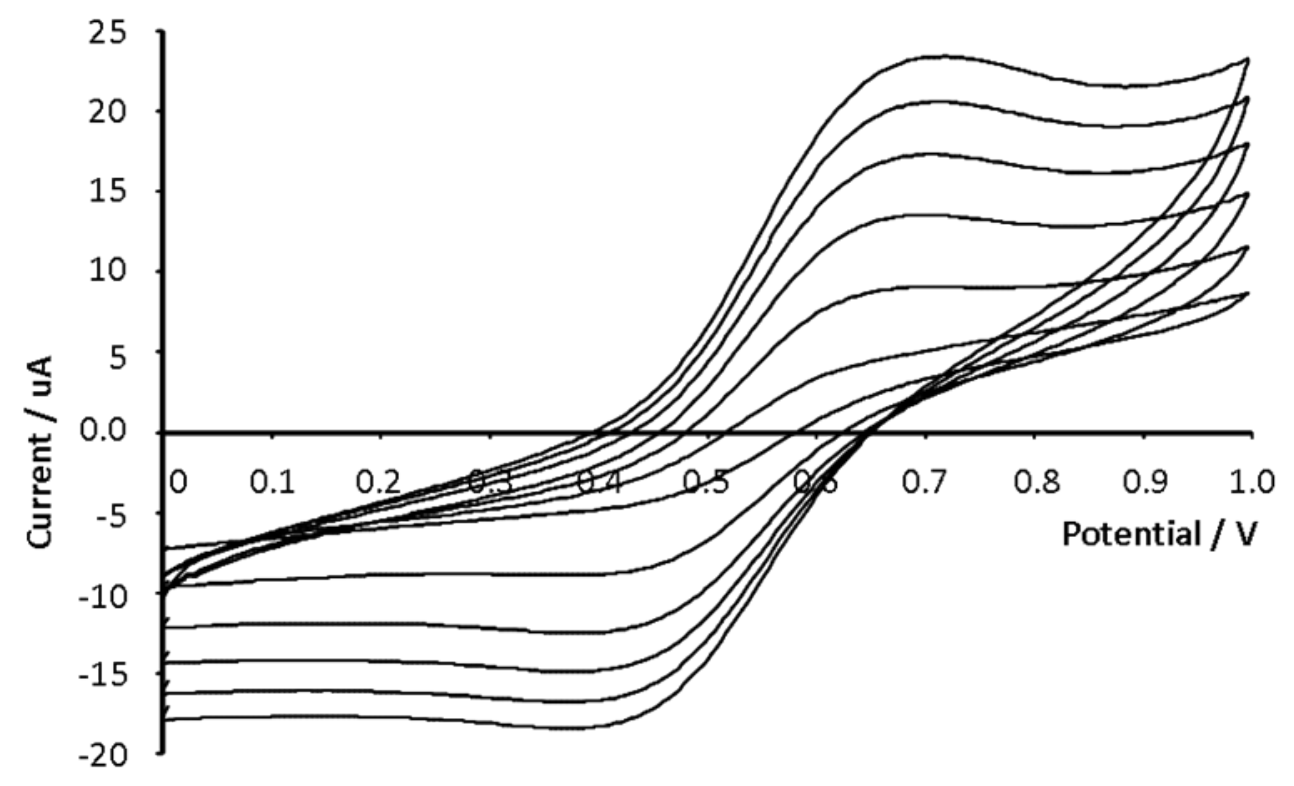

Figure 3. The cyclic voltammogramm of $\left[\mathrm{Cu}(\mathrm{II}) \mathrm{S}_{\mathrm{pr}} \mathrm{N}_{\mathrm{en}}\left(\left(\mathrm{CH}_{2}\right)_{2} \mathrm{SPh}_{2}\right] 2 \mathrm{BF}_{4}(2 \mathrm{mM})\right.$ in acetonitrile/t ${ }^{\mathrm{BuNBF}} \mathrm{NB}_{4}(0.1 \mathrm{M})$ at scan rates of $10,40,80,120,160$ and $200 \mathrm{mVs}^{-1}$. The $\mathrm{E}^{2}$ values (table 2 ) were referenced to the normal hydrogen electrode using a ferrocene standard.

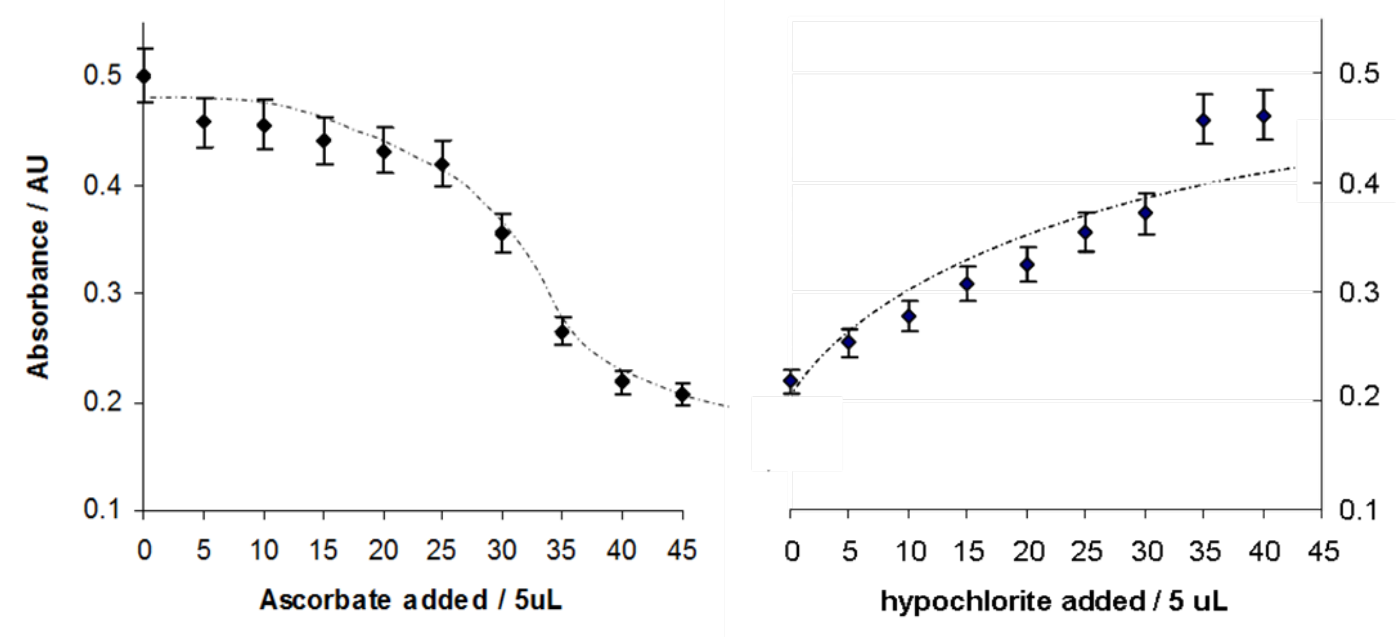

Figure 4. The chemical reduction of $\left[\mathrm{Cu}(\mathrm{II}) \mathrm{S}_{\mathrm{pr}} \mathrm{N}_{\mathrm{en}}\left(\left(\mathrm{CH}_{2}\right)_{2} \mathrm{SPh}\right)_{2}\right]^{2+}$ by ascorbic acid (left) followed by the chemical re-oxidation using hypochlorite (right). The figure is a composite of the data from two separate titrations. 


\section{Copper complexes as a source of redox active MRI contrast agents.}

Lynsey Dunbar, Rebecca J. Sowden, Katherine D. Trotter, Michelle K. Taylor, David Smith, Alan R. Kennedy, John Reglinski and Corinne M. Spickett

\section{Supporting Information}

Competitive binding studies: Rather than measure the formation constants to arrive at a value which has limited biological impact, we elected to challenge our copper complexes directly with bovine serum albumin (BSA). This simple experiment is designed to probe stability of our copper complexes directly in competition with BSA, which is a major metal scavenger present in the blood stream. This simple, direct experiment more closely models the sequestration of metals in-vivo.

Reaction of the copper(II) complexes with bovine serum albumin (BSA): $0.3 \mathrm{mM}$ solutions of each of the copper macrocycles and BSA (199 mg, $1 \mathrm{~mL}$ ) were prepared in Tris-HCl buffer (5 mM, pH 7.4). A $1.0 \mathrm{~mL}$ volume of the solution of each of the required copper complexes was placed in a $1.5 \mathrm{~mL}$ quartz cuvette $(1.0 \mathrm{~cm}$ path length) and the spectrum was recorded between 200 and $800 \mathrm{~nm}$ against a Tris-buffer reference placed in a matched cuvette. BSA solution was titrated in aliquots of $20 \mu \mathrm{L}$ into the cuvette.
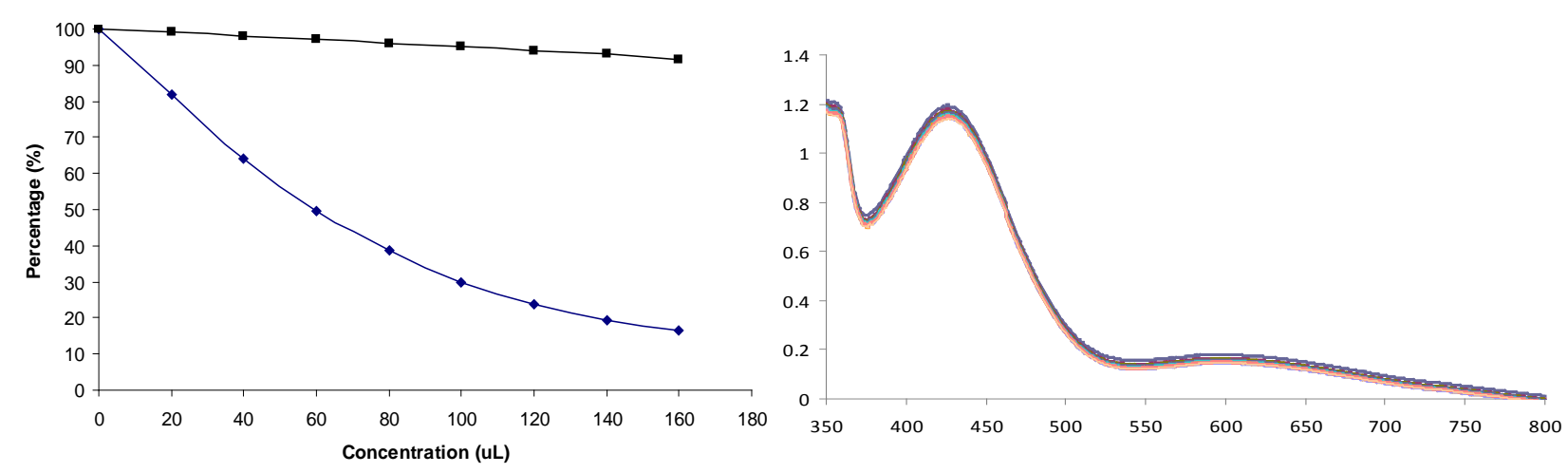

Figure ESI1: Left: The spectrophotometric titrations (412 nm) of cis-[Cu(II) $\left.\mathrm{S}_{\mathrm{pr}} \mathrm{N}_{\mathrm{en}}\right]^{2+}$ (adapted from Sowden et al.) and cis- $\left[\mathrm{Cu}(\mathrm{II}) \mathrm{S}_{\mathrm{pr}} \mathrm{N}_{\mathrm{en}}\left(-\left(\mathrm{CH}_{2}\right)_{3} \mathrm{OH}\right)_{2}\right]^{2+}$. Right: The spectrophotometric titrations (350-800) of cis- $\left[\mathrm{Cu}(\mathrm{II}) \mathrm{S}_{\mathrm{pr}} \mathrm{N}_{\text {en }}\left(-\left(\mathrm{CH}_{2}\right)_{3} \mathrm{OH}\right)_{2}\right]^{2+}:(0.3 \mathrm{mM}$ in 5 $\mathrm{mM}$ Tris buffer at $\mathrm{pH} 7.4$ ) with BSA solution (199 $\mathrm{mg}, 1 \mathrm{~mL})$. A small diminution in the spectrum of cis-[Cu(II)S $\left.\mathrm{S}_{\mathrm{pr}} \mathrm{N}_{\mathrm{en}}\left(-\left(\mathrm{CH}_{2}\right)_{3} \mathrm{OH}\right)_{2}\right]^{2+}$ of the absorbance occurs owing to dilution of the sample as the titrant is added. The integrity of the complex (cis-[Cu(II) $\mathrm{S}_{\mathrm{pr}} \mathrm{N}_{\mathrm{en}}(-$ $\left.\left.\left.\left(\mathrm{CH}_{2}\right)_{3} \mathrm{OH}\right)_{2}\right]^{2+}\right)$ is maintained throughout and the copper is not being sequestered from the ligand cavity. 
Sowden RJ et al (2013) Biometals 26: 85-95. 